\title{
SPINAL INJURIES IN JUVENILES
}

\author{
Necropsy Findings in Twelve Cases
}

\section{Aufdermaur, Lucerne, Switzerland}

From the Pathological Institute, Cantonal General Hospital, Lucerne

Injuries of the spine are rare in children (Jaki 1930, Arendt 1958, Gelehrter and Vitalli 1960, Howarth and Petrie 1964, Vinz 1964, Broger 1968), amounting to only 2.5 per cent (Gelehrter 1957) or 3.3 per cent (Forni 1947) of all spinal injuries. During eight years we have observed twelve of a total of 100 spinal injuries in subjects between the ages of nothing and eighteen years coming to necropsy; this incidence thus exceeds that shown in clinical reports. The difference may be due to differences in the material studied; necropsy may disclose injuries which are not always recognisable by clinical and radiological methods.

\section{MATERIAL AND METHODS}

The twelve spines were dissected by hand from the occiput down to the coccyx. The ribs were removed with scissors and the pelvis with a saw. Subsequently, the spines were freed from attached tissues, sawn sagittally and radiographed laterally. Then the vertebral bodies with the intervertebral discs as well as the postero-lateral joints of the entire spine were examined histologically. Similarly, we dissected twenty intact spines from juveniles of the same age group; these spines were stretched in a vice and bent manually in an attempt to produce fractures; they were radiographed and the injured sites were examined histologically. In addition the normal histological structure of the cervical, thoracic and lumbar parts of twenty-three spines from subjects nothing to eighteen years old was examined.

Radiography-Radiographs taken while the patients were alive have not been published, nor were any taken in the present series of cases. In radiographs taken at necropsy, the fracture is represented by a small or gaping fissure (Figs. 3 and 4). In its course through the cartilage layer, the fissure is limited towards the intervertebral disc by a delicate calcific line (Fig. 7). In some cases a wide intervertebral space may suggest the presence of the lesion. In cases with a small fissure and in which all or most of the ligaments are intact, radiological identification of the injury may be difficult because of overlying soft tissues. Because there is damage of the growth zone, a circumscribed deformity of a vertebral body found at an advanced age may in some cases be considered as the result of such an injury.

\section{RESULTS}

Normal histology-The cartilaginous end-plates of the vertebral bodies consist of cells, ground substance and fibrous lamellae. In the columnar and in the calcifying cartilage of the growth zone, the fibrous lamellae are spread apart by the cell columns (Fig. 1). From the second year of life there are many "ossification gaps"-microscopic foci of necrotic cartilage-in the columnar as well as in the calcifying cartilage (Figs. 2 and 5). In seventeen- and eighteen-yearold subjects the growth zones of most cartilage plates were no longer intact but were represented by single or multiple cartilaginous foci, extending through a quarter to four-fifths of the vertebral width (Fig. 2). Pyknosis, pale nuclei and empty cartilage capsules, present from the seventh and more distinctly from the eighth year of life, appeared regularly in the growth zone between the ossification gaps (Fig. 5).

Findings in the spinal column after trauma-Observations in our twelve cases are summarised in Table I. The first decade of life is represented twice as often as the second. With one exception (Case 8), only boys were affected. The injuries consisted in severance of the cartilaginous end-plate of the vertebral bodies (Figs. 3 to 5). Most commonly involved was 


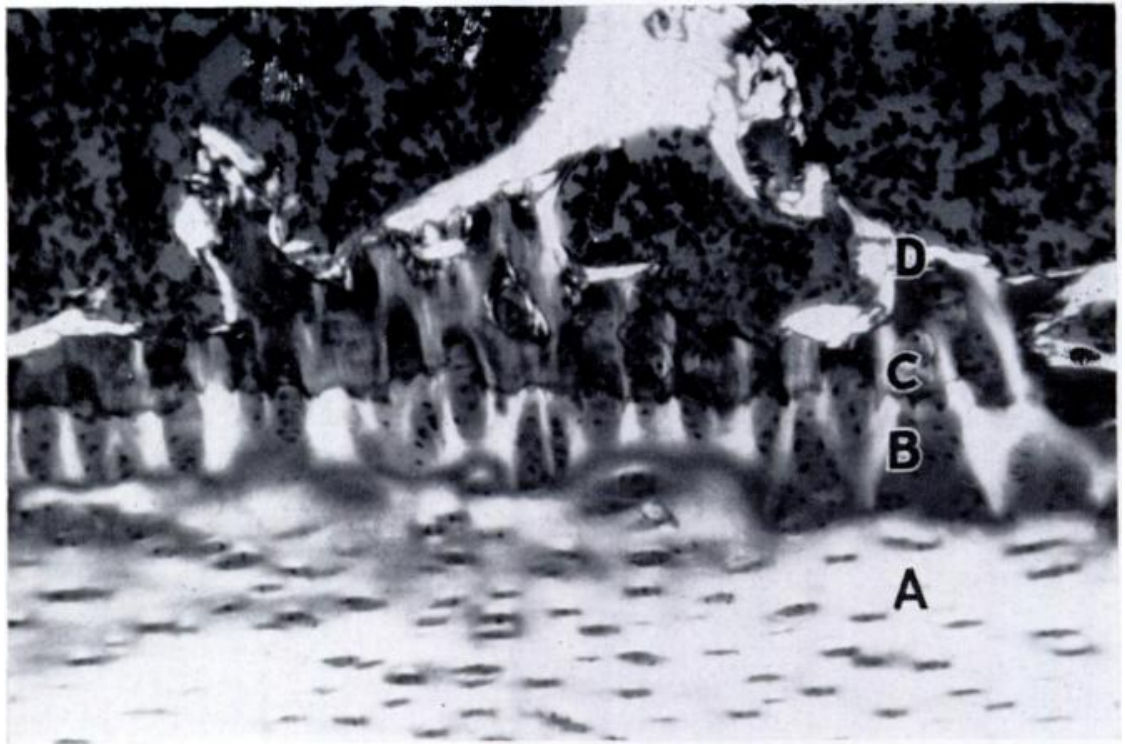

FIG. 1

Female, $2 !$ years. Base-plate of the eleventh thoracic vertebral body in polarised light. In comparison with the resting cartilage the fibrous lamellae of the growth zone are loosened. A - Resting cartilage. $B=$ Columnar cartilage. $C=$ Calcified cartilage. $D=-$ Bony lamellae of the vertebral body.

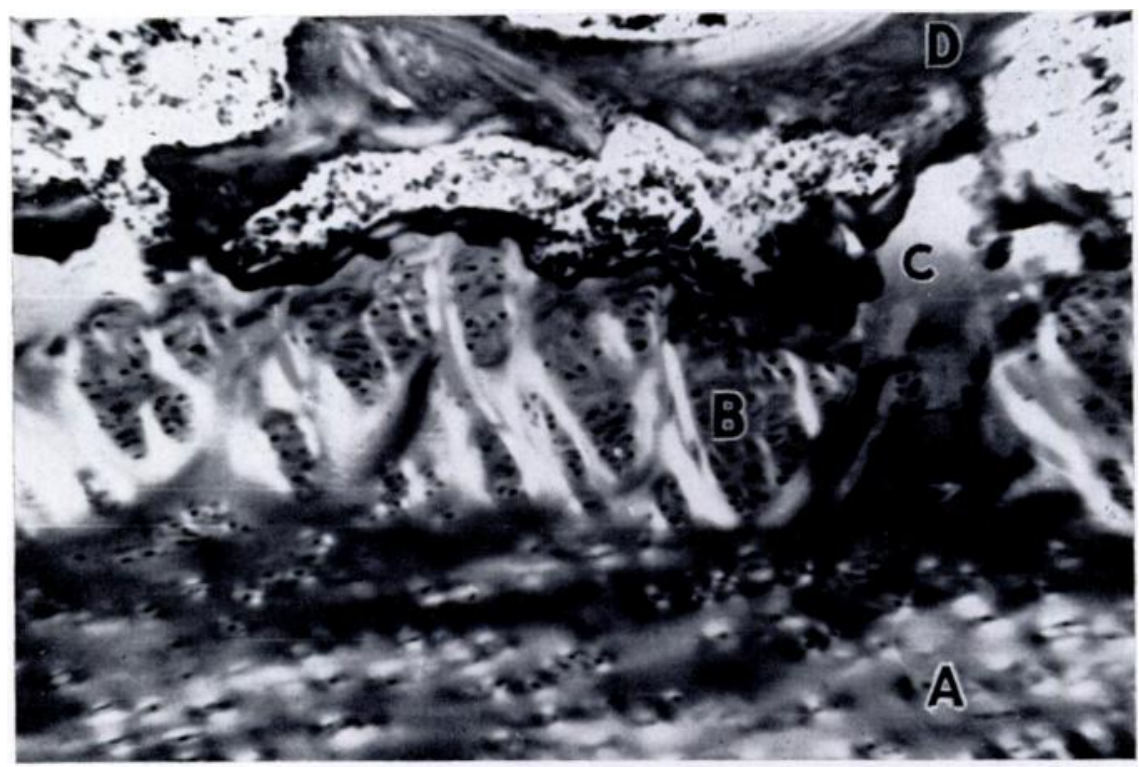

FiG. 2

Male, 18 years. Ground plate of the eighth thoracic vertebral body in polarised light. Growth zone preserved. $A=$ Resting cartilage. $B=$ Growing cartilage. $C=$ Ossification gap. $\mathrm{D}=$ Bony lamellae of the vertebral body.

the cervical spine (seven cases); the thoracic spine was next (four cases) and the lumbar spine last (one case). In ten instances the injury occurred in road traffic accidents; in two there was hyperextension of the spine during childbirth.

Clinically, spinal fracture was suspected once (Case 2). In the other eleven cases the spinal injury was first noted at necropsy. Four patients could not be examined clinically 


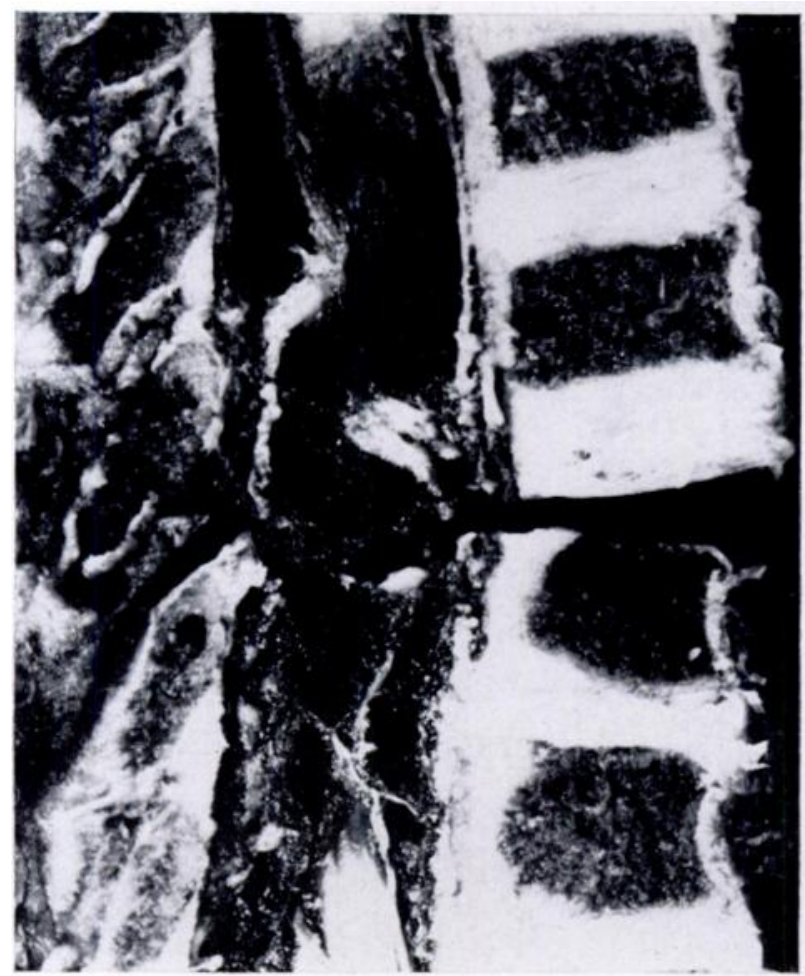

FIG. 3

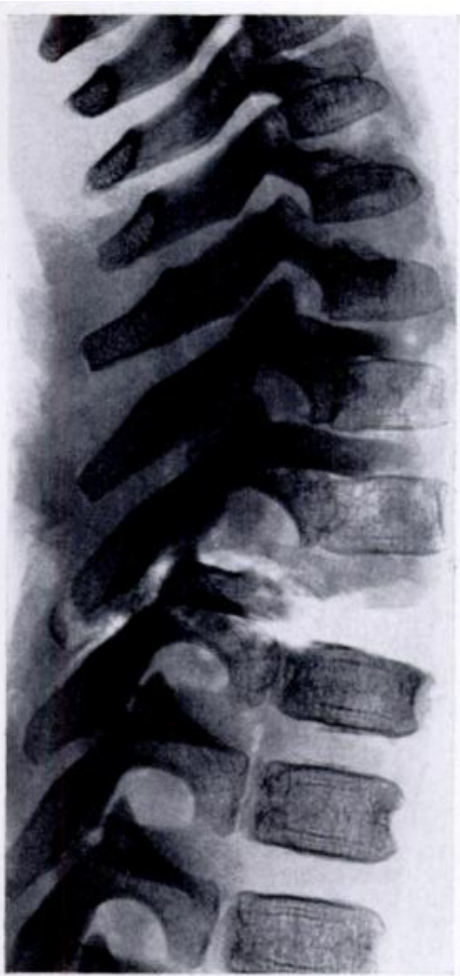

FIG. 4

Case 3-Male, 2 years. Unstable injury. Large, gaping fissure of the top plate of the third thoracic vertebral body with rupture and haemorrhage in ligaments, spinal cord and capsules of the posterolateral joints. Epidural and subdural haematoma. Figure 3-Necropsy specimen. Figure 4Radiograph of specimen.

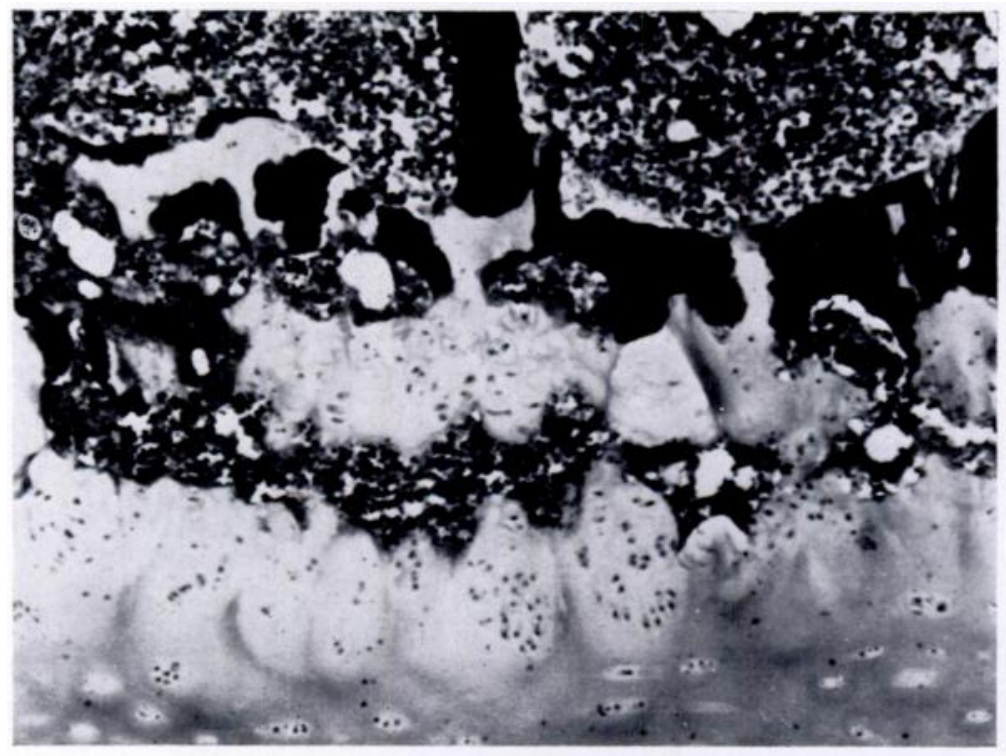

Fig. 5

Case 9-Male, 13 years. Fracture of the base plate of the first thoracic vertebral body in the columnar cartilage. In the left part of the figure, the vertebral marrow space is opened by the fracture. (Van Gieson stain, $\times 90$.) 
TABLE I

Clinical and Pathological Details in Twelve Cases

\begin{tabular}{|c|c|c|c|c|c|c|}
\hline Number & Sex & $\begin{array}{c}\text { Age } \\
\text { (years) }\end{array}$ & Injury & Accident & Cause of death & $\begin{array}{l}\text { Time } \\
\text { accident/death }\end{array}$ \\
\hline 1 & Male & Still birth & Top plate C. 6 & Birth injury & Hydrops congenitus & 0 \\
\hline 2 & Male & Still birth & Top plate C.5 & Birth injury & $\begin{array}{l}\text { Cervical epidural haematoma } \\
\text { up to the occipital bone }\end{array}$ & 0 \\
\hline 3 & Male & 2 & $\begin{array}{l}\text { Top plate T.3 } \\
\text { Top plate T.8 } \\
\text { Base plate T.3 }\end{array}$ & $\begin{array}{l}\text { Knocked down } \\
\text { by a car }\end{array}$ & $\begin{array}{l}\text { Cervical epidural and subdural } \\
\text { haematoma. Fracture of the } \\
\text { temporal bone with subdural } \\
\text { haematoma and cerebral oedema }\end{array}$ & 11 days \\
\hline 4 & Male & 3 & Top plate C. 3 & $\begin{array}{l}\text { Knocked down } \\
\text { by a car }\end{array}$ & $\begin{array}{l}\text { Haemothorax following } \\
\text { rib fractures }\end{array}$ & 12 hours \\
\hline 5 & Male & 4 & $\begin{array}{l}\text { Top plate T.7 } \\
\text { Top plate T.10 }\end{array}$ & $\begin{array}{l}\text { Knocked down } \\
\text { by a car }\end{array}$ & $\begin{array}{l}\text { Haemoperitoneum from rupture } \\
\text { of the liver }\end{array}$ & 2 hours \\
\hline 6 & Male & $4 \frac{1}{2}$ & Top plate L.2 & $\begin{array}{c}\text { Knocked down } \\
\text { by a car }\end{array}$ & $\begin{array}{l}\text { Haemoperitoneum due to } \\
\text { splenic rupture }\end{array}$ & hours \\
\hline 7 & Male & 5 & Base plate C.2 & $\begin{array}{c}\text { Knocked down } \\
\text { by a car }\end{array}$ & Contusion with cerebral oedema & 1 day \\
\hline 8 & Female & 8 & Base plate C. 6 & $\begin{array}{l}\text { Knocked down } \\
\text { by a car }\end{array}$ & $\begin{array}{l}\text { Tears of the ligaments and } \\
\text { joint capsules between the } \\
\text { occipital bone and atlas. } \\
\text { Cervical epidural haematoma. } \\
\text { Cerebral oedema }\end{array}$ & 1 hour \\
\hline 9 & Male & 13 & Base plate T.1 & $\begin{array}{l}\text { Knocked down } \\
\text { by bus }\end{array}$ & $\begin{array}{l}\text { Laceration of the brain } \\
\text { and heart }\end{array}$ & 0 \\
\hline 10 & Male & 17 & $\begin{array}{l}\text { Top plate T. } 2 \\
\text { Top plate T.3 }\end{array}$ & $\begin{array}{l}\text { Collision on } \\
\text { bicycle with car }\end{array}$ & Fat embolism from fractures & 1 day \\
\hline 11 & Male & 18 & $\begin{array}{l}\text { Top plate C. } 6 \\
\text { Base plate C.4 } \\
\text { Base plate C. }\end{array}$ & $\begin{array}{c}\text { Knocked down } \\
\text { by a car }\end{array}$ & $\begin{array}{l}\text { Skull fracture with subdural } \\
\text { haematoma and cerebral oedema }\end{array}$ & $\begin{array}{l}\text { "shortly } \\
\text { afterwards" }\end{array}$ \\
\hline 12 & Male & 18 & Top plate C. 3 & $\begin{array}{l}\text { In car run } \\
\text { against tree }\end{array}$ & Contusion with cerebral oedema & $\begin{array}{l}\text { "immediately } \\
\text { afterwards" }\end{array}$ \\
\hline
\end{tabular}

(Cases 8, 9, 11 and 12). In all cases death occurred within one and a half days after the accident.

Causes of death-In Case 2 there was a cervical epidural haematoma extending to the occipital bone, caused by severance of the upper cartilaginous plate of the fifth cervical vertebra and the longitudinal ligaments. In two cases there was cervical epidural and subdural haematoma spreading to the occipital bone, owing to rupture of the top plate of the third thoracic vertebra and the longitudinal ligaments (Case 3, Figs. 3 and 4) or of the base plate of the sixth cervical vertebra and the longitudinal ligaments (Case 8). An accessory cause of death in these two cases was cerebral oedema due to skull trauma. In nine cases the spinal injuries did not contribute to death, which was caused by injuries to other organs, and, in Case 1, by hydrops congenitus.

Necropsy-At necropsy the completely or partly severed cartilage plates were seen. In two instances there was also rupture of the anterior longitudinal ligament. In three cases, in addition to the rupture of the cartilage plate and the longitudinal ligaments, the supraspinous and intraspinous ligaments, the ligamenta flava and the capsules of the postero-lateral joints were also ruptured (Cases 2, 3 and 8).

Histologically the fracture lines involved almost exclusively the two layers of the growth zone (Fig. 5). These layers were split in irregularly wavy lines. In all cases the vertebral marrow 
space was opened and there was blood at the fracture site (Fig. 5). In Case 3 the dissection could be traced over a short distance into the primary spongiosa of the third thoracic vertebra. In Case 6 the upper anterior edge of the second lumbar vertebra was broken off. In the seventeen- and eighteen-year-old patients (Cases 10,11 and 12) the injury involved mostly the preserved growth zone (Fig. 6). In an eighteen-year-old male the growth zone of the base plate of the fifth cervical vertebra was split across the dorsal half of the vertebra. In the

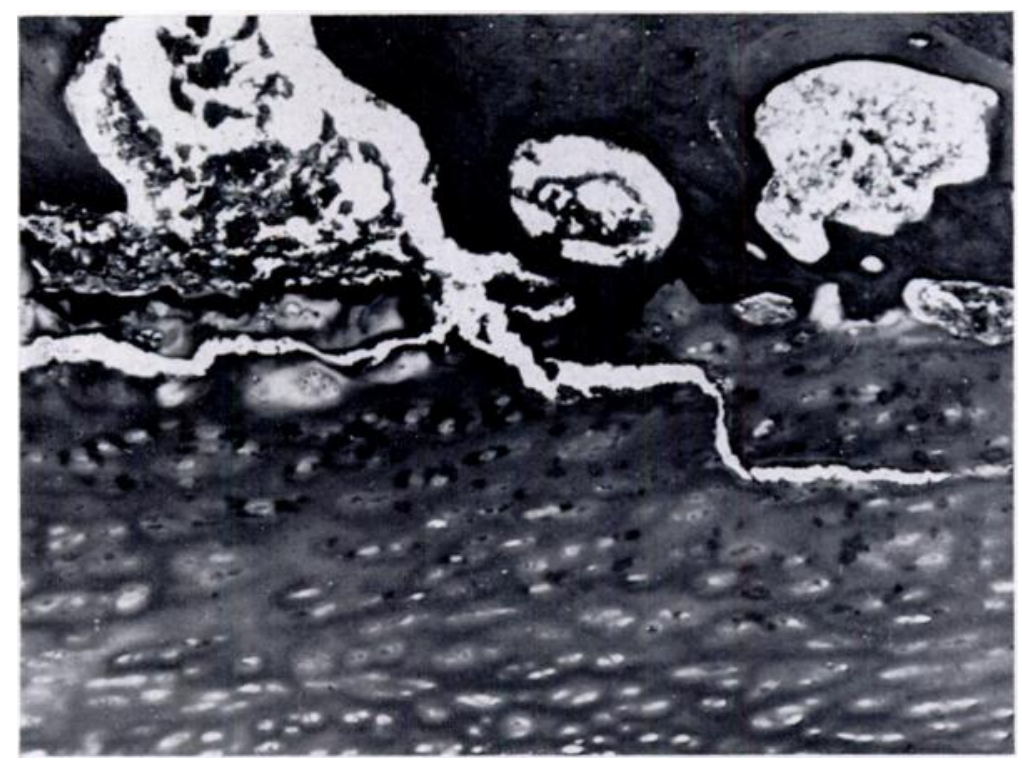

FIG. 6

Case 11-Male, 18 years. The growth zone of the base plate of the fifth cervical vertebral body is preserved in its dorsal half and split (left part of figure). In the middle of the vertebra (centre of figure) the growth zone is interrupted. From here, the dissection enters the resting cartilage and ends after a short S-shaped course. At the fissure the vertebral marrow space connects with the fracture. (Van Gieson stain, $\therefore 70$.)

centre of the Figure the growth zone is interrupted; it is exactly here that the fracture changes direction, and after a short $\mathrm{S}$-shaped course it ends in the resting cartilage.

\section{EXPERIMENTAL INJURIES OF DISSECTED SPINAL COLUMNS}

Forced bending of the spinal columns stretched in a vice caused fractures in the growth zones of the cervical, thoracic or lumbar spine. The cracks were demonstrated in radiographs (Fig. 7) and in histological sections. They show the same arrangement as those observed in the twelve patients. There was never rupture of intervertebral discs or a recognisable fracture of the bone proper.

\section{DISCUSSION}

Spinal injuries in persons between the ages of nothing and eighteen years appear not to be so rare as was supposed. In our series they made up 12 per cent of all spinal injuries. Males predominated by eleven to one, a ratio which also holds true for adults with injuries of the spine (Lob 1954, Campanacci 1964, Stringa 1965, Rüdy 1969). In all cases the cartilaginous end-plate was split (Figs. 3 and 4); in eight patients one, in two patients two and in another two patients three cartilage plates were fractured. The top plate was injured in twelve and the base plate in six instances, giving a ratio of two to one. Histologically, findings in the cervical, thoracic and lumbar vertebrae were similar. They were situated in the growth zone and consisted of 
irregularly wavy cracks in the columnar and in the calcified cartilage (Fig. 5). In two instances some primary spongiosa was fragmented (Cases 3 and 6). In no case was there an extended fracture of the vertebral bone, a rare occurrence in children. In no instance was the intervertebral disc torn. The presence of cells with pale or pyknotic nuclei and empty cartilage capsules at the edge of a fracture does not permit an estimate of the age of the injury. Such findings occur normally in the growth zones from the seventh to eighth year of life. Lesions similar to those seen after accidents may be produced by forced bending of a juvenile spine.

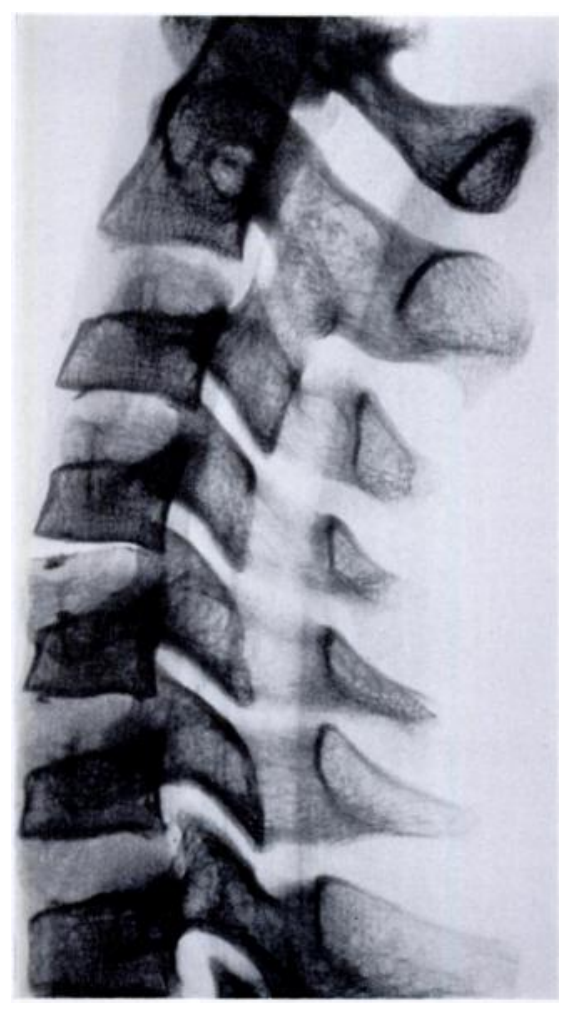

Fig. 7

Radiograph of the spine of a boy aged 15 years taken after experimental fracture. The forced bend caused separation of the base plate of the fourth cervical vertebral body. The tear is sharply limited by calcified cartilage.

Ruptures of the intervertebral disc and extensive vertebral fractures have not appeared under experimental conditions either.

Various authors mention the detachment of an end-plate from the vertebral body as a rare injury in juveniles (Ruge 1933, Hoffmeister 1964, Schmorl and Junghanns 1968), without describing histological findings. In our observations the injury consisted not in detachment, but in splitting of the cartilage plate of the growth zone. Special histological conditions may predispose to these lesions: the ground substance is well-developed in the growth zone. The fissures pass through the edge or through the anuclear ossification gaps without changing direction. Thus, there is no evidence that cells and ground substance play a role in the origin of the lesions. The fibre systems, however, show a remarkable arrangement in the growth zone, deviating considerably from those of the resting cartilage. In the latter they are closely packed; in the former they are spread apart and loosened by the columnar arrangement of the cells in the proliferating and calcifying zones (Figs. 1 and 2). This configuration might decrease resistance to mechanical stress. Loosening of the fibrous lamellae in the cartilage plates of juvenile or adult spines occurs commonly in the lower thoracic and in the lumbar segments. This may result in prolapse of intervertebral discs into the vertebral body (Schmorl's nodes). The generalisation of this phenomenon leads to the picture of Scheuermann's adolescent kyphosis (Aufdermaur 1964). Traumatic ruptures are located more commonly through such loosened foci of the cartilage plate than at a distance (Aufdermaur 1965). These findings as well as the present observations suggest that the resting cartilage with its closely apposed fibrous lamellae offers more resistance toexogenous forces than places without (adolescent kyphosis) or with loosened fibrous lamellae. Findings such as those shown in Figure 6 also suggest a predilection of the growth zone to traumatic damage.

In three instances, spinal fractures accounted fully (Case 2) or partly (Cases 3 and 8) for the death of the subjects. In all three cases the ligaments between the vertebrae and the capsules of the postero-lateral joints were also ruptured (unstable injuries). The other nine observations concerned stable injuries in which all or most of the ligaments were not ruptured having no significance as causes of death. Unstable injuries are therefore considered to be more serious than stable injuries (Howarth and Petrie 1964, Kaufer and Hayes 1966, Holdsworth 1970, Roberts and Curtiss 1970, Burke 1971). 


\section{SUMMARY}

In the necropsy material presented there were, among 100 spinal injuries occurring during the past eight years, twelve in juveniles up to eighteen years of age. In all cases, the growth zone of the cartilaginous end-plate of the spine was fractured. The special histological architecture of the growth zones with their loosened fibrous lamellae might play a decisive role in the localisation of the lesions. The clinical importance of this type of injury and the radiological findings are discussed.

\section{REFERENCES}

ARENDT, W. (1958): Luxationsfraktur der unteren Brustwirbelsäule beim Säugling. Archiv für orthopädische und Unfall-Chirurgie, 50, 120-123.

Aufdermaur, M. (1964): Zur Pathogenese der Scheuermannschen Krankheit. Deutsche medizinische Wochenschrift, 89, 73-76.

Aufdermaur, M. (1965): Zur pathologischen Anatomie der Scheuermannschen Krankheit. Schweizerische medizinische Wochenschrift, 95, 264-268.

Blount, W. P. (1954): Fractures in Children. Baltimore: The Williams \& Wilkins Company.

Broger, E. (1968): Rara frattura del rachide cervicale nella prima infanza. Chirurgia degli organi di movimento, 57, 70-74.

Burke, D. C. (1971): Hyperextension injuries of the spine. Journal of Bone and Joint Surgery, 53-B, 3-12.

CAMpannaCi, M. (1964): Fratture vertebrali (revisione di 707 casi trattati per lesione traumatica recente). II. Frattura cervicali. Chirurgia degli organi di movimento, 52, 454-465.

Campannaci, M., Cenni, F., and Manzoni, A. (1964): Fratture vertebrali (revisione di 707 casi trattati per lesione traumatica recente). I. Frattura toraco-lombari (610 osservazioni). Chirurgia degli organi di movimento, 52, 439-453.

ForNi, I. (1947): Le fratture del rachide nel bambino. Chirurgia degli organi di Movimento, 31, 347-361.

Gelehrter, G. (1957): Die Wirbelkörperbrüche im Kindes- und Jugendalter. Archiv für orthopädische und Unfall-Chirurgie, 49, 253-263.

Gelehrter, G., and Vitalli, H.-P. (1960): Verletzungsformen der Halswirbelsäule mit Ausnahme der Kopfgelenke. Archiv für orthopädische und Unfall-Chirurgie, 52, 287-310.

HOFFMeISTER, H. P. (1964): Beitrag zur Wirbelsäulenverletzung beim Neugeborenen. Geburtshilfe und Frauenheilkunde, 24, 1085-1090.

Holdsworth, F. (1970): Fractures, dislocations, and fracture-dislocations of the spine. Journal of Bone and Joint Surgery, 52-A, 1534-1551.

Howarth, M. B., and Petrie, J. G. (1964): Injuries of the Spine. Baltimore: The Williams \& Wilkins Company.

JÁKI, J. (1930): Beiträge zur Lehre von den Wirbelsäulenverletzungen. Archiv für orthopädische und UnfallChirurgie, 28, 640-679.

KaUfer, H., and HAYES, J. T. (1966): Lumbar fracture-dislocation. Journal of Bone and Joint Surgery, 48-A, $712-730$.

LoB, A. (1954): Die Wirbelsäulenverletzungen und ihre Ausheilung. Second edition. Stuttgart: Georg Thieme.

ROBERTS, J. B., and CURTISs, P. H., Jun. (1970): Stability of the thoracic and lumbar spine in traumatic paraplegia following fracture or fracture-dislocation. Journal of Bone and Joint Surgery, 52-A, 1115-1130.

Ruge, E. (1933): Die geschlossenen Verletzungen der Wirbelsäule. Ergebnisse der Chirurgie und Orthopädie, 26, 63-173.

RüDY, K. (1969): Zustandekommen und Folgeerscheinungen von Verletzungen der Wirbelsäule. Schw'eizerische medizinische Wochenschrift, 99, 1433-1438.

Schmorl, G., and Junghanns, H. (1968): Die gesunde und die kranke Wirbelsäule in Röntgenbild und Klinik. Fifth edition. Stuttgart: Georg Thieme.

Stringa, G. (1965): Lesioni traumatiche della colonna cervicale (statistica e classificazione). Archivio "Putti" di chirurgia degli organi di movimento, 20, 53-77.

VinZ, H. (1964): Die Subluxationen im Bereich der oberen Halswirbelsäule bei Kindern. Archiv für orthopädische und Unfall-Chirurgie, 56, 531-542. 